\title{
Salinivibrio costicola subsp. vallismortis subsp. nov., a halotolerant facultative anaerobe from Death Valley, and emended description of Salinivibrio costicola
}

\author{
Chi-Yu Huang, ${ }^{1 \dagger}$ Jean-Louis Garcia, ${ }^{2}$ Bharat K. C. Patel, ${ }^{3}$ Jean-Luc Cayol, ${ }^{2}$ \\ Larry Baresi ${ }^{4}$ and Robert A. Mah ${ }^{1}$
}

\begin{abstract}
Author for correspondence: Jean-Louis Garcia. Tel: +334918285 72. Fax: +33491828570. e-mail: garcia@esil.univ-mrs.fr
\end{abstract}

1 University of California Los Angeles, School of Public Health, Department of Environmental Health Sciences, Los Angeles, CA 90024-1772, USA

2 IRD, Laboratoire de Microbiologie, Université de Provence, ESIL case 925 163 Av. de Luminy, 13288 Marseille Cedex 9, France

3 School of Biomolecular and Biomedical Sciences, Faculty of Science, Griffith University, Brisbane, Queensland 4111, Australia

4 California State University Northridge, 18111 Nordhoff St, Northridge, CA 91330-8303, USA

\begin{abstract}
Strain DV', a halotolerant, Gram-negative, facultatively anaerobic bacterium, was isolated from a hypersaline pond located in Death Valley, California. The cells were non-spore-forming, motile, curved rods (1.0-1.8 $\times 0.5-0.6 \mu \mathrm{m})$ and occurred singly, in pairs or rarely in chains. Strain DV ${ }^{\top}$ was oxidase-, catalase-, Voges-Proskauer-, amylase-, gelatinase- and lipase-positive and indolenegative. Nitrate, sulfate and fumarate were not used as electron acceptors. Carbohydrates served as energy sources both aerobically and anaerobically. Strain $\mathrm{DV}^{\top}$ grew optimally at $37^{\circ} \mathrm{C}$ (temperature range $20-50{ }^{\circ} \mathrm{C}$ ) with $2.5 \%$ $\mathrm{NaCl}(\mathrm{NaCl}$ range $0-12.5 \%)$ and $\mathrm{pH} \mathrm{7.3} \mathrm{(pH} \mathrm{range} \mathrm{of} \mathrm{5.5-8.5)} \mathrm{in} \mathrm{a} \mathrm{glucose/yeast}$ extract medium with a doubling time of $20 \mathrm{~min}$ (aerobically) or $41 \mathrm{~min}$ (anaerobically). The end products of glucose fermentation were ethanol, isobutyrate, propionate, lactate, formate and $\mathrm{CO}_{2}$. Strain $\mathrm{DV}^{\top}$ was resistant to penicillin, D-cycloserine, streptomycin and tetracycline $\left(200 \mu \mathrm{g} \mathrm{ml}^{-1}\right)$. The $\mathrm{G}+\mathrm{C}$ content was $50 \mathrm{~mol} \%$. 16S rRNA gene sequence analysis indicated that it was closely related to Salinivibrio costicola (97.7\%) and this was confirmed by DNA-DNA hybridization (93\% relatedness). However, phenotypic characteristics such as halotolerance, gas production, growth at $50{ }^{\circ} \mathrm{C}$, antibiotic resistance, sugar-utilization spectrum and phylogenetic signatures are sufficiently different from Salinivibrio costicola to warrant designating strain $\mathrm{DV}^{\top}$ as a new subspecies of Salinivibrio costicola, Salinivibrio costicola subsp. vallismortis subsp. nov. (= DSM 8285').
\end{abstract}

Keywords: Salinivibrio costicola subsp. vallismortis subsp. nov., halotolerance, facultative anaerobe, taxonomy

\section{INTRODUCTION}

Hypersaline ecosystems are extreme environments and are generally inhabited by a limited variety of halophilic bacterial species, even though a wide range of substrates are available for growth. The dead cell bodies or metabolic end-products of invertebrates, algae and prokaryotes are the major sources of

\footnotetext{
†Present address: Department of Environmental Science, Tunghai University, Taichung 40704, Taiwan.

Abbreviation: VFA, volatile fatty acid.

The GenBank accession number for the 16S rRNA gene sequence of strain $D^{\top}$ is AF057016.
}

oxidizable compounds in these environments (Ollivier et al., 1994). Brine shrimps or brine flies produce proteins and chitin. Cyanobacteria and Halobacteriaceae at high salt concentrations provide significant quantities of organic matter from decomposition of their cell walls, which are composed of sugars, proteins and lipids. Organic osmolytes, which maintain cell turgor pressure under high salt concentrations, also contribute to the overall carbon cycle in hypersaline ecosystems. In addition to potassium, halophilic bacteria accumulate low-molecular-mass organic compounds (such as betaine) to adapt to osmotic stress (Galinski \& Trüper, 1982; Reed et al., 1986; Robertson et al., 1990, 1992; Lai et al., 1991; Lai \& Gunsalus, 1992). 
Relatively little work has been reported on the diversity of anaerobic halophilic microbes or the breakdown of organic matter under anaerobic saline conditions. Increasing salt concentration results in an abnormal accumulation of $\mathrm{H}_{2}$ (Zeikus, 1983) and a diversity of volatile fatty acids (VFA) in sediments (Klug et al., 1985; Oren, 1988), suggesting that oxidation of organic matter is incomplete at high levels of $\mathrm{NaCl}$, as compared with other ecosystems (digestors, marine ecosystems, etc.), where methane is the end product. Accumulation of $\mathrm{H}_{2}$, acetate and other VFAs indicates that interspecies hydrogen transfer metabolism is limited in hypersaline environments. Even if VFAs are oxidized, the process is very slow as compared with the fermentative metabolism of carbohydrates and other substrates used by most anaerobes. Consequently, VFAs, $\mathrm{H}_{2}$ and other end-products accumulate (Oren, 1988).

The ability to grow at varying concentrations of salt is used to classify halophilic microbes into three groups (Larsen, 1962): (i) the slight halophiles (optimum growth at $2-5 \% \mathrm{NaCl}$ ), (ii) the moderate halophiles (optimum growth at $5-20 \% \mathrm{NaCl}$ ) and (iii) the extreme halophiles (optimum growth at 20-30\% $\mathrm{NaCl}$ ). The three types have been reported to occur in anaerobic saline habitats (Vreeland \& Hochstein, 1993). Most bacteria isolated from sea water are also found in hypersaline waters and, in particular, members of the genus Vibrio (Ramos-Cormenzana, 1993), which are slightly halophilic, tend to dominate. We have isolated a new strain from sediment samples collected from a hypersaline pond located in Death Valley, California. The site, located $86 \mathrm{~m}$ below sea level, is the lowest land point in the United States. A huge surface of this area is covered by a large amount of salt. About 10000 years ago, the increasingly arid climate transformed Lake Manly, which used to occupy the valley, into the current salt flats.

\section{METHODS}

Origin of sample. Sediment and water samples were collected from a site at Badwater, Death Valley, California. Sediment samples were collected from underneath a salt-encrusted layer immersed under several centimetres of water. The samples were kept under anaerobic conditions in the dark, transported at ambient temperature to our laboratory and processed within $48 \mathrm{~h}$. The chemical composition of the water from Badwater was marginally different from that of sea water (low in magnesium and chloride but high in calcium, sulfate and carbonate) and contained (as percentages): sodium, $3 \cdot 4$; calcium, $0 \cdot 28$; phosphate, $0 \cdot 19$; magnesium, 0.37; chloride, 4.78; sulfate, 1.06; and carbonate, $0 \cdot 23$.

Isolation and culture techniques. A modified HS-1 medium (Liaw \& Mah, 1992), prepared aerobically or anaerobically, was used for enrichment and axenic cultures. The anaerobic technique of Hungate (1969), modified for use with syringes (Macy et al., 1972), was used. The medium contained $\left(1^{-1}\right)$ : $1 \mathrm{~g} \mathrm{NH}_{4} \mathrm{Cl}, 7 \mathrm{~g} \mathrm{MgCl}_{2} .6 \mathrm{H}_{2} \mathrm{O}, 9.6 \mathrm{~g} \mathrm{MgSO}_{4} .7 \mathrm{H}_{2} \mathrm{O}, 0.5 \mathrm{~g}$ $\mathrm{CaCl}_{2} .2 \mathrm{H}_{2} \mathrm{O}, 3 \cdot 8 \mathrm{~g} \mathrm{KCl}, 0 \cdot 4 \mathrm{~g} \mathrm{~K}_{2} \mathrm{HPO}_{4} \cdot 3 \mathrm{H}_{2} \mathrm{O}, 3 \mathrm{~g} \mathrm{Na}_{2} \mathrm{CO}_{3}$,
$120 \mathrm{~g}$ (for enrichment) or $25 \mathrm{~g}$ (for axenic culture) $\mathrm{NaCl}$, $10 \mathrm{ml}$ trace mineral solution (Balch et al., 1979) and, for anaerobic cultures, $0.5 \mathrm{~g}$ L-cysteine and $0.001 \mathrm{~g}$ resazurin. Anaerobic medium was prepared by boiling the medium under a stream of $\mathrm{N}_{2} / \mathrm{CO}_{2}(70: 30, \mathrm{v} / \mathrm{v})$ gas, cooling it to room temperature and dispensing it, while flushing with $\mathrm{N}_{2} / \mathrm{CO}_{2}$ gas, into culture tubes $(9 \mathrm{ml})$ or into serum bottles $(25 \mathrm{ml})$. Both types of vessel were then sealed with rubber septa and aluminium crimp cap seals (Bellco Glass). Aerobic medium was prepared by dispensing $9 \mathrm{ml}$ medium into $16 \times 150 \mathrm{~mm}$ culture tubes and capping the tubes loosely with plastic caps. All media were then autoclaved at $121^{\circ} \mathrm{C}$ for $20 \mathrm{~min}$. Prior to inoculation, sterile stock solutions were added to the pre-dispensed autoclaved medium to obtain a final concentration of $0.5 \%$ glucose, $0.1 \%$ yeast extract (for both aerobic and anaerobic medium) and $0.3 \% \mathrm{NaHCO}_{3}$ and $0.05 \% \mathrm{Na}_{2} \mathrm{~S} .9 \mathrm{H}_{2} \mathrm{O}$ (for anaerobic medium). For preparation of roll tubes, $1 \cdot 8 \%$ Bacto-agar (Difco) was added to the medium.

Enrichments were initiated by inoculating a few grams of the sediment sample to a serum bottle containing $25 \mathrm{ml}$ anaerobic enrichment medium $(12 \% \mathrm{NaCl}$ and $0.5 \%$ glucose $)$ followed by incubation at $37^{\circ} \mathrm{C}$ without shaking. Cultures were transferred five times at intervals of $3 \mathrm{~d}$ with a $10 \%$ inoculum prior to culture purification. Cultures were purified by the repeated use of the roll-tube method of Hungate (1969). Culture purity was assessed from the uniformity of colony morphology and by examination of single cells in phase-contrast microscopy.

Physiological and biochemical tests. Unless indicated, all experiments were conducted in triplicate. The effect of $\mathrm{NaCl}$ on growth was determined in anaerobic culture medium. A culture resulting from four successive growths in anaerobic medium lacking $\mathrm{NaCl}$ was used as inoculum to avoid carryover of $\mathrm{NaCl}$. The effect of temperature was determined by using aerobic growth medium containing the optimum salt concentration. The effect of salt concentrations and of various temperatures on growth were also determined by using the aerobic growth medium. The effect of $\mathrm{pH}$ was tested aerobically by using two organic buffers, MES and 1,3-bis[tris(hydroxymethyl)methylamino]propane (Bis-Tris propane), at a final concentration of $500 \mathrm{mM}$. The heat resistance of cells was determined in growth medium. After 1 and $2 \mathrm{~d}$ incubation at $37^{\circ} \mathrm{C}$, duplicate cultures were heated at 90 or $100{ }^{\circ} \mathrm{C}$ for $20 \mathrm{~min}$ and subcultured into fresh growth medium [inoculum, 20\% (v/v)]. The resulting cultures were incubated at $37^{\circ} \mathrm{C}$ for $2 \mathrm{~d}$. In addition, cultures grown (i) in the basal medium or (ii) in the basal medium enriched with $5 \mathrm{~g}$ yeast extract and bio-Trypticase $1^{-1}$ were examined for the presence of spores at different growth phases.

The ability to oxidize or ferment a variety of substrates was determined by using glucose-free aerobic and anaerobic media containing the test substrate (final concentration of $0.5 \%$ ). The growth rate for each test compound was compared with that of a control tube containing $0 \cdot 1 \%$ yeast extract only. The criterion for positive substrate utilization was based on achieving a maximum growth rate of at least $0 \cdot 2 \mathrm{~h}^{-1}$. Prototrophic growth was tested in the aerobic medium containing glucose but no yeast extract.

Biochemical tests were conducted as described by Smibert \& Krieg (1981) and by using API Rapid NFT strips (API Analytab Products). Gram reaction was determined by using heat-fixed liquid cultures stained with a Difco Gram stain kit. Microscopic examination of cultures grown under 
different conditions was used to determine sporulation. The effect of antibiotics on growth was determined aerobically by using D-cycloserine, penicillin-G, streptomycin and tetracycline at concentrations ranging from 100 to $600 \mu \mathrm{g} \mathrm{ml}^{-1}$. Oxygen was tested as an electron acceptor in liquid and solid media. Fumarate $(10 \mathrm{mM})$, nitrate $(10 \mathrm{mM})$ and sulfate $(10 \mathrm{mM})$ with lactate as carbon source were tested as electron acceptors in anaerobic liquid medium. Growth on $\mathrm{H}_{2} / \mathrm{CO}_{2}$ gas mixture $(80: 20)$ was examined in anaerobic liquid medium in order to test for homoacetogenesis.

Analytical techniques. Growth rates were determined by measuring the $\mathrm{OD}_{560}$ of cultures using a Perkin-Elmer Junior model 35 spectrophotometer. VFAs, carboxylic acids and gases from the fermentation of glucose were analysed from culture supernatants by gas chromatography (CordRuwisch et al., 1986) and by HPLC (Shimadzu) with a reverse-phase $\mathrm{mC} 18$ column $(4 \mathrm{~mm} \times 30 \mathrm{~cm}$ Spherisorb C18; Interchim) and a UV SPD-6A spectrophotometric detector (Shimadzu) at a wavelength of $225 \mathrm{~nm}$. The mobile phase consisted of $20 \%$ acetonitrile in $0.01 \mathrm{M}$ chlorhydric acid. $\mathrm{H}_{2} \mathrm{~S}$ was determined photometrically as colloidal $\mathrm{CuS}$ after reaction with a mixture containing $50 \mathrm{mM} \mathrm{HCl}$ and $5 \mathrm{mM}$ $\mathrm{CuSO}_{4}$ (Cord-Ruwisch, 1985).

Scanning microscopy. Cells were fixed in $2.5 \%$ glutaraldehyde in $0 \cdot 1 \mathrm{M}$ cacodylate buffer and were attached to polylysine-coated glass coverslips by using $0 \cdot 1 \%$ aqueous polylysine. They were then rinsed in cacodylate buffer followed by dehydrating in a $30-100 \%$ acetone series, and dried in liquid $\mathrm{CO}_{2}$. Samples were sputter coated with about $10 \mathrm{nM}$ gold and viewed under a Philips model SEM 501 scanning electron microscope. Photographs were taken at $10000 \times$ magnification using a Polaroid type 55-P/N film.

DNA base composition and DNA relatedness. DNA was extracted by the technique of Pitcher et al. (1989). The $\mathrm{mol} \% \mathrm{G}+\mathrm{C}$ content was determined at the DSMZ according to Mesbah et al. (1989) and Tamaoka \& Komagata (1984). DNA-DNA hybridization studies were performed at the DSMZ and the procedures have been reported previously (Mechichi et al., 1998).

Isolation of nucleic acids and sequencing. The methods for the extraction and purification of genomic DNA have been described previously (Redburn \& Patel, 1993). Twelve primers, as described previously for the Bacteria domain (Andrews \& Patel, 1996), were used to amplify the 16S rRNA gene from genomic DNA. The amplified product was purified (Redburn \& Patel, 1993; Andrew \& Patel, 1996) and the sequence was determined with an ABI automated DNA sequencer by using a Prism dideoxy terminator cycle sequencing kit and the protocol recommended by the manufacturer (Applied Biosystems).

The 16S rRNA gene sequence that we determined was aligned manually with reference sequences of various members of the domain Bacteria by using the ae 2 alignment editor (Maidak et al., 1996). All reference sequences were obtained from the Ribosomal Database Project (Maidak et al., 1996) with the exception of the sequences of Salinivibrio costicola NCIMB 701 ${ }^{\mathrm{T}}$, S. costicola AV3, S. costicola E-367, S. costicola V-15, S. costicola 6 and S. costicola $\mathrm{H}-178$, which were extracted from the EMBL database under accession numbers X95527 to X95532, respectively. Positions of sequence and alignment uncertainty were omitted from the analysis. Pairwise evolutionary distances based on 1319 unambiguous nucleotides were computed by using the method of Jukes \& Cantor (1969) and dendrograms were constructed from these distances by using the neighbourjoining method. Both programs form part of the PHYLIP package (Felsenstein, 1993).

\section{RESULTS}

\section{Isolation}

A short vibrio with a tendency to form chains was isolated from the environmental sample and designated strain $\mathrm{DV}^{\mathrm{T}}$. Axenic cultures of strain $\mathrm{DV}^{\mathrm{T}}$ were obtained by inoculating Hungate roll tubes after several successive transfers of the glucose enrichment. Strain $\mathrm{DV}^{\mathrm{T}}$ was the predominant organism in the enrichment at this time and was the only colonyforming organism at the highest dilutions.

\section{Morphology}

Colonies grown in anaerobic roll tubes and on aerobic agar plates were similar in morphology. They were round with entire edges, smooth, convex, opaque and white. Colony diameter reached $3 \mathrm{~mm}$ in 1 week on aerobic agar plates. The cells of strain $\mathrm{DV}^{\mathrm{T}}$ were small, curved rods ranging from 1.0 to 1.8 by 0.5 to $0.6 \mu \mathrm{m}$ in size (Fig. 1), very motile in young cultures by means of one or rarely two subpolar flagella (Fig. 2), but nonmotile in old cultures. Cells occurred singly, in pairs or in chains, as observed normally for other vibrios. Strain DV ${ }^{\mathrm{T}}$ stained Gram-negative. Spores were not observed.

\section{Growth and physiology}

Strain $\mathrm{DV}^{\mathrm{T}}$ was a chemoorganotrophic facultative anaerobe and, hence, the conditions for optimum growth were determined under anaerobic and aerobic conditions. The isolate grew in $\mathrm{NaCl}$ concentrations ranging from 0 to $12.5 \%$, with the optimal concentration being $2.5 \%$ (Fig. 3a). The optimum temperature for growth was $37^{\circ} \mathrm{C}$, and no growth was observed above $50{ }^{\circ} \mathrm{C}$ or below $20^{\circ} \mathrm{C}$ (Fig. 3b). The optimum $\mathrm{pH}$ for growth was $7 \cdot 3$ and the $\mathrm{pH}$ growth range was $5 \cdot 5-8 \cdot 5$ (Fig. 3c). The doubling time for strain $\mathrm{DV}^{\mathrm{T}}$ in the presence of glucose and yeast extract under optimal conditions was 20 min aerobically and $41 \mathrm{~min}$ anaerobically. Growth occurred in mineral medium with glucose as sole carbon and energy source.

Under aerobic conditions, strain $\mathrm{DV}^{\mathrm{T}}$ used the following substrates: D-glucose, D-mannose, sucrose, trehalose, D-gluconate, pyruvate, adipate, caprate, Lglutamic acid and yeast extract. Slight growth was observed on D-xylose, L-histidine and L-proline. The following compounds were not used: L-arabinose, cellobiose, D-galactose, D-galacturonate, lactose, maltose, L-rhamnose, salicin, citrate, 2-oxoglutarate, DL-lactate, L-malate, malonate, phenylacetate, propionate, valerate, ethanol, D-mannitol, $m$-inositol, D-sorbitol, DL- $\alpha$-alanine, $\beta$-alanine, L-leucine, L-serine, L-tyrosine, benzoate, $p$-hydroxybenzoate, betaine, sarcosine and spermine. 


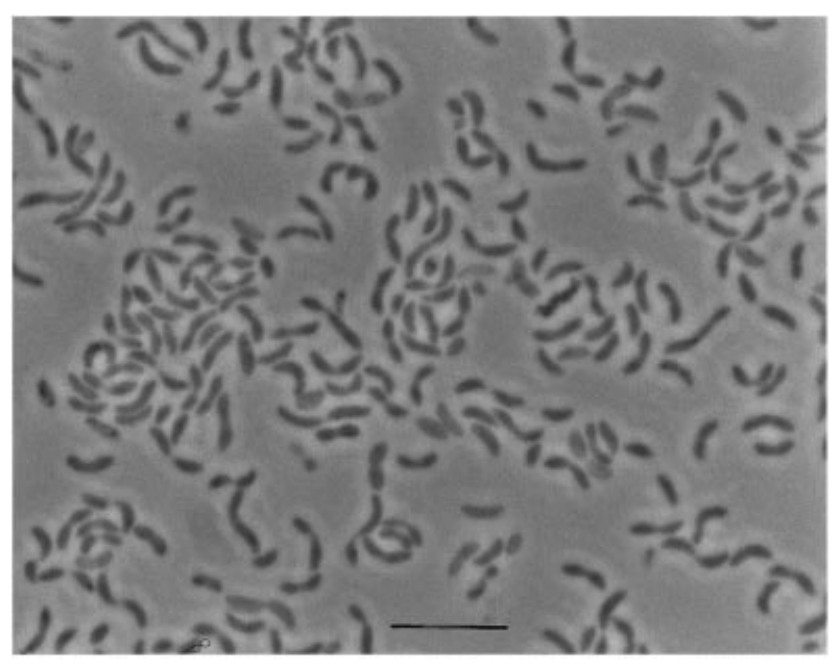

Fig. 1. Phase-contrast micrograph of strain $\mathrm{DV}^{\top}$. Bar, $5 \mu \mathrm{m}$.

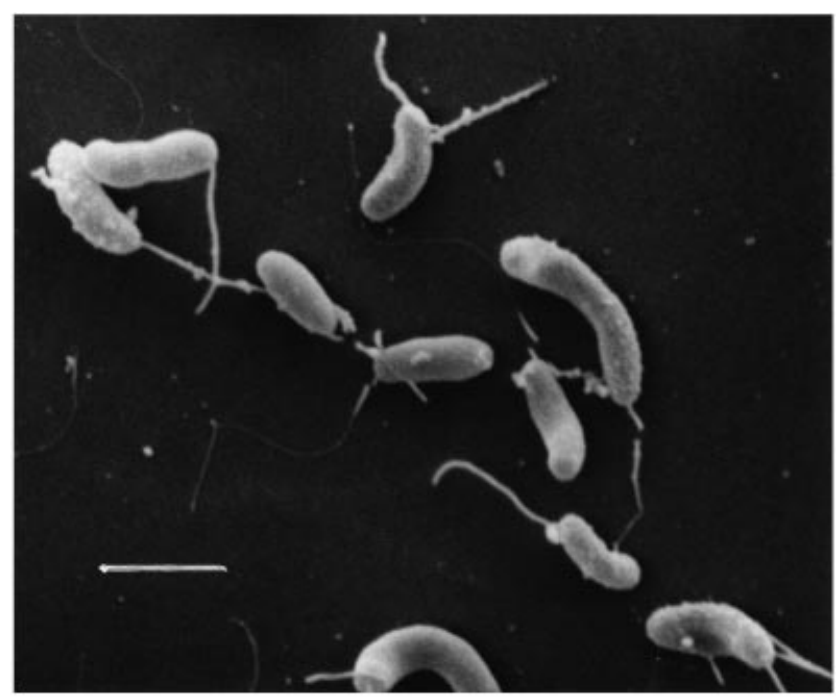

Fig. 2. Scanning electron micrograph of strain $D^{\top}$. Bar, $2 \mu \mathrm{m}$.

The following substrates were fermented anaerobically: cellobiose, fructose, glucose, maltose, mannose, trehalose, $N$-acetylglucosamine, glycogen, starch and pyruvate. The following compounds were not fermented: arabinose, galactose, lactose, melibiose, raffinose, rhamnose, ribose, sucrose, xylose, adonitol, dulcitol, erythritol, glycerol, inositol, mannitol, methanol, sorbitol, formate, acetate, butyrate, propionate, ascorbate, citrate, fumarate, lactate, oxalate, succinate, tartrate, betaine, methylamine, trimethylamine, sarcosine, Casamino acids, cellulose, chitin and pectin.

The only end-products detected from glucose $(28 \mathrm{mM})$ fermentation by strain $\mathrm{DV}^{\mathrm{T}}$ after $24 \mathrm{~h}$ at $37^{\circ} \mathrm{C}$ were: $15 \mathrm{mM}$ ethanol, $8 \mathrm{mM}$ isobutyric acid, $8 \mathrm{mM}$ propionic acid, $3 \mathrm{mM}$ lactic acid, $1 \mathrm{mM}$ formic acid and only $\mathrm{CO}_{2}$ in the gas phase. Fumarate, nitrate and sulfate did not serve as electron acceptors. No growth was observed on $\mathrm{H}_{2} / \mathrm{CO}_{2}$.

The following biochemical tests were positive for strain $\mathrm{DV}^{\mathrm{T}}$ : oxidase, catalase, amylase, gelatinase, lipase, arginine dihydrolase and Voges-Proskauer. Negative results were shown for aesculin and urea hydrolysis, $\beta$-galactosidase, lysine and ornithine decarboxylase activities and indole production. Strain $\mathrm{DV}^{\mathrm{T}}$ was insensitive to antibiotics and growth was only inhibited by streptomycin at a concentration of $200 \mu \mathrm{g} \mathrm{ml}^{-1}$, by penicillin-G at $250 \mu \mathrm{g} \mathrm{ml}^{-1}$ and by both $\mathrm{D}$-cycloserine and tetracycline at $600 \mu \mathrm{g} \mathrm{ml} \mathrm{m}^{-1}$. Protoplasts were observed when the isolate was grown on penicillin-G or D-cycloserine.

\section{DNA studies}

The $\mathrm{G}+\mathrm{C}$ content of DNA from strain $\mathrm{DV}^{\mathrm{T}}$ determined in triplicate by HPLC was $50 \mathrm{~mol} \%$. DNADNA hybridization studies indicated that strain $\mathrm{DV}^{\mathrm{T}}$ and $S$. costicola were closely related (93\% similarity).

\section{S rRNA sequence analysis}

By using 12 primers, an almost complete sequence was determined, consisting of 1548 nucleotides corresponding to positions 8-1542 (Escherichia coli numbering according to Winker \& Woese, 1991). The comparison of 1319 unambiguous bases of the $16 \mathrm{~S}$ rRNA gene of strain $\mathrm{DV}^{\mathrm{T}}$ with sequences from other members of the domain Bacteria indicated its close relationship to $S$. costicola. Phylogenetic analysis revealed that strain $\mathrm{DV}^{\mathrm{T}}$ was a member of the family Vibrionaceae and the closest relative was $S$. costicola (mean similarity $97.7 \%$ ). A dendrogram generated by the neighbour-joining method showing this relationship is shown in Fig. 4.

\section{DISCUSSION}

The salt content of the pond known as Badwater in Death Valley, California, from which strain $\mathrm{DV}^{\mathrm{T}}$ was isolated, is close to that of sea water, although periodically, and between rains, the salinity must approach saturation. At the time of sampling, a salt crust had formed, floating below the water surface, close to the bottom sediment. The sample was collected from the sediment layer below the brine, after breaking through the crust. Although the sample contained only $3.76 \% \mathrm{NaCl}$ (determined by drying and weighing triplicate samples), the presence of a salt crust indicated considerable periodic concentration of the brine, sufficient to elicit precipitation of salt, which would consequently create a localized high-salt environment. Strain $\mathrm{DV}^{\mathrm{T}}$ is unusual among vibrios as it is halotolerant (does not need $\mathrm{NaCl}$ ) and yet requires $2.5 \%$ $\mathrm{NaCl}$ for optimal growth. However, it is not surprising to have isolated such a strain from such an environment, which fluctuates in salinity. 

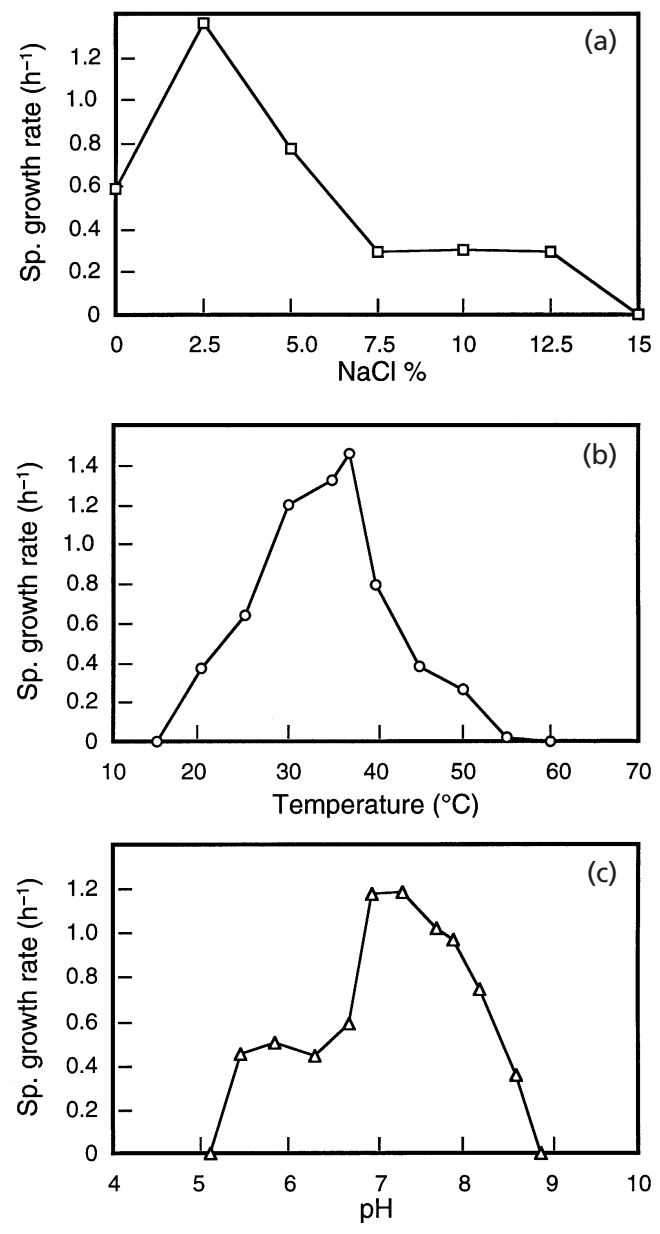

Fig. 3. Effects of $\mathrm{NaCl}$ concentration (a), temperature (b) and $\mathrm{pH}$ (c) on growth of strain $\mathrm{DV}^{\top}$. The experiments were conducted with anaerobic culture medium adjusted to the optimum conditions required for growth with the exception of the parameter to be determined. Sp., Specific.

Cells of three genera of the family Vibrionaceae, namely Photobacterium, Aeromonas and Plesiomonas, are straight rods (Baumann \& Schubert, 1984) and hence, on morphology alone, strain $\mathrm{DV}^{\mathrm{T}}$ can be excluded from these genera. The genera Vibrio and Salinivibrio are the only genera that contain curved cells resembling strain $\mathrm{DV}^{\mathrm{T}}$. However, $16 \mathrm{~S}$ rRNA gene sequence analysis revealed that the closest relative of strain $\mathrm{DV}^{\mathrm{T}}$ is $S$. costicola (mean similarity $97.7 \%$ ). Therefore, characterization of strain $\mathrm{DV}^{\mathrm{T}}$ is based on a comparison with $S$. costicola, which is the only species so far described for this genus (Mellado et al., 1996).

The strains of $S$. costicola can be differentiated from members of the genus Vibrio on the basis of two unique helical sequences and secondary structures between positions 178 to 197 and 197 to 219 of the rRNA ( $E$. coli $16 \mathrm{~S}$ rRNA gene sequence numbering according to Winker \& Woese, 1991) (Mellado et al., 1996). Strain $\mathrm{DV}^{\mathrm{T}}$ contains a genus signature in its $16 \mathrm{~S}$ rRNA that is the same as that of $S$. costicola strains between positions 197 and 219, but a secondary structure that is similar to that of Vibrio species rather than that of $S$. costicola strains between positions 178 and 197 (Fig. 5). It has been suggested that, if the level of $16 \mathrm{~S}$ rDNA similarity is greater than $97 \%$, other additional phenotypic and/or genotypic characteristics should be used for taxonomic purposes (Stackebrandt \& Goebel, 1994).

From the phenotypic characteristics exhibited by the new isolate, some notable traits appear very important for distinguishing strain $\mathrm{DV}^{\mathrm{T}}$ from previously described strains of $S$. costicola (Table 1). S. costicola is a moderate halophile, optimum growth of which occurs at $10 \% \mathrm{NaCl}$, but it is unable to grow at $\mathrm{NaCl}$ concentrations lower than $1 \cdot 2-1 \cdot 5 \%$ or at $50{ }^{\circ} \mathrm{C}$. It cannot produce gas from glucose and ferments galactose, mannose, mannitol and sucrose. L-Alanine, lactate and mannitol are used aerobically as sole carbon and energy sources but mannose is not, and amylase is negative (Garcia et al., 1987; Farmer \& Hickman-Brenner, 1992). As strain $\mathrm{DV}^{\mathrm{T}}$ and $S$. costicola differ in many phenotypic characteristics, this reflects heterogeneity of the genomes of the two isolates. However, DNA relatedness studies indicate a very close relationship (similarity of $93 \%$ ) and, according to current taxonomic norms, strain $\mathrm{DV}^{\mathrm{T}}$ should be accorded the status of a strain of $S$. costicola rather than a new species. We therefore propose that strain $\mathrm{DV}^{\mathrm{T}}$ should be designated Salinivibrio costicola subsp. vallismortis subsp. nov., which automatically creates Salinivibrio costicola subsp. costicola subsp. nov. The different nucleotide signatures for the two strains will enable their distribution in saline and hypersaline environments to be studied more readily.

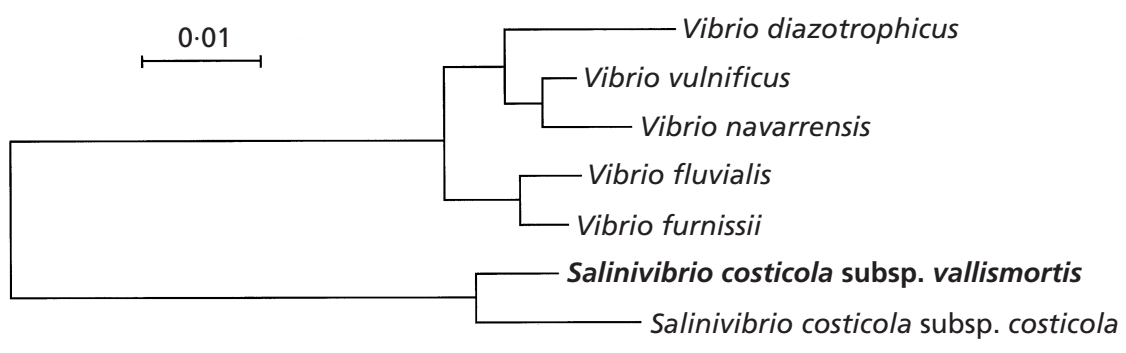

Fig. 4. Unrooted dendrogram showing the phylogenetic position of strain $\mathrm{DV}^{\top}$ within the radiation of the members of the genera Vibrio and Salinivibrio. The tree was determined by using 1319 unambiguous nucleotides of the $16 \mathrm{~S}$ rDNA using the Jukes and Cantor and neighbour-joining methods. All six sequences of $S$. costicola used in the analysis were identical and hence only the sequence of the type strain $\mathrm{NCIMB} 701^{\top}$ is represented in the dendrogram. Bar, evolutionary distance of 0.01 . 

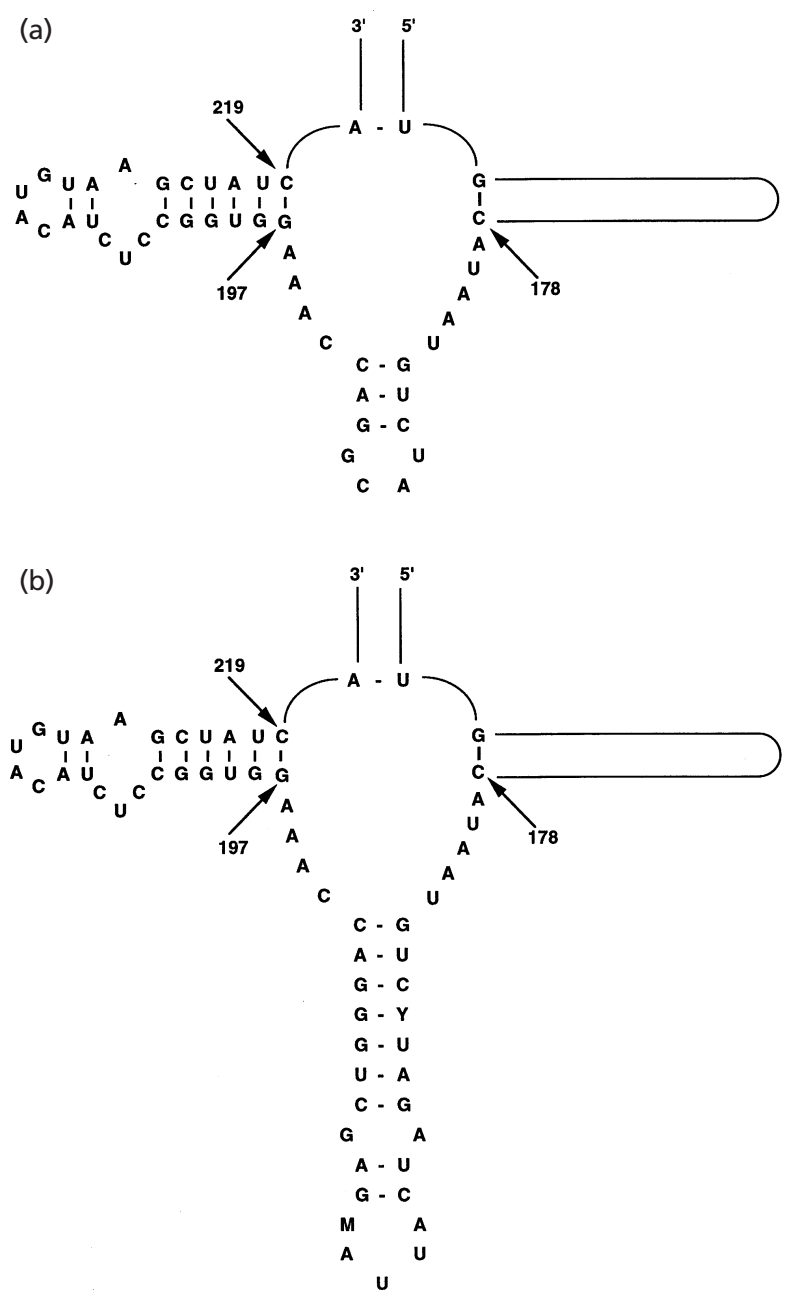

Fig. 5. Comparison of the secondary $16 \mathrm{~S}$ rRNA structures from strain $D V^{\top}$ (a) and S. costicola (b). The numbers represent the two helices from positions 178 to 197 and from 197 to 219 (E. coli numbering according to Winker \& Woese, 1991).

\section{Emended description of Salinivibrio costicola Mellado et al. 1996}

Salinivibrio costicola (cos.ti'co.la. L. n. costa rib; L. subst. cola dweller; M.L. n. costicola rib-dweller).

Cells are Gram-negative, non-spore-forming, curved rods, $0.5-0.6 \times 1.0-3.2 \mu \mathrm{m}$, highly motile by means of one or rarely two subpolar flagella. Occur singly, in pairs or rarely in chains. Circular, convex, opaque, smooth, cream-coloured pigmented colonies (2-3 $\mathrm{mm})$. The optimum $\mathrm{NaCl}$ concentration for growth is between 2.5 and $10 \%(\mathrm{w} / \mathrm{v})$ at $37{ }^{\circ} \mathrm{C}$; grows at $\mathrm{NaCl}$ concentrations between 0 and $20 \%$ (w/v). Growth at 5-50 ${ }^{\circ} \mathrm{C}$ and $\mathrm{pH} 5-10$ (optimal growth at $37^{\circ} \mathrm{C}$ and $\mathrm{pH} 7 \cdot 3-7 \cdot 5)$. No growth factors are required for growth, but yeast extract enhances growth.

Facultative anaerobe, chemoorganotrophic. Catalase and oxidase are produced. Gelatin and casein are hydrolysed; Voges-Proskauer and arginine decarboxylase tests are positive. Indole, $\beta$-galactosidase, lysine and ornithine decarboxylase tests are negative. Nitrates usually not reduced to nitrites; no reduction of nitrite. Acid is produced aerobically from D-glucose, sucrose, D-trehalose and xylose. D-Glucose, Dtrehalose, $\mathrm{N}$-acetylglucosamine and pyruvate are fermented.

Isolated from hypersaline habitats and from salted food. $\mathrm{G}+\mathrm{C}$ content of the DNA is between 49.4 and $50 \cdot 5 \mathrm{~mol} \%$. The type strain is NCIMB $701^{\mathrm{T}}$.

\section{Description of Salinivibrio costicola subsp. costicola subsp. nov.}

Salinivibrio costicola subsp. costicola (cos.ti'co.la. L. n. costa rib; L. subst. cola dweller; M.L. n. costicola ribdweller).

Cells are Gram-negative, non-spore-forming, curved rods, $0.5 \times 1.5-3.2 \mu \mathrm{m}$, motile by means of one polar flagellum. Circular, convex, opaque, cream-coloured pigmented colonies $(2-3 \mathrm{~mm})$ develop on $10 \%$ (w/v) marine salts solid medium after $2 \mathrm{~d}$ incubation at $37^{\circ} \mathrm{C}$. No pigments. Broth culture is uniformly turbid. The optimum marine salts concentration for growth is $10 \%(\mathrm{w} / \mathrm{v})$ at $37{ }^{\circ} \mathrm{C}$; grows at marine salts concentrations between 0.5 and $20 \%(\mathrm{w} / \mathrm{v})$. No growth in the absence of $\mathrm{NaCl}$. Growth at $5-45^{\circ} \mathrm{C}$ and $\mathrm{pH} 5-10$

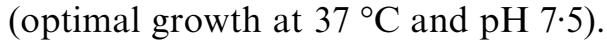

Facultative anaerobe. Catalase and oxidase are produced. Acid is produced from D-glucose, maltose and D-trehalose; acid is not produced from Darabinose, inositol, lactose or D-xylose. Gelatin and casein are hydrolysed; starch is not hydrolysed. Voges-Proskauer and arginine decarboxylase tests are positive. Indole, $\beta$-galactosidase, lysine and ornithine decarboxylase tests are negative. Nitrates usually not reduced to nitrites; no reduction of nitrite. The following compounds are utilized as sole carbon and energy sources: D-trehalose, glycerol, acetate, $\mathrm{N}$ acetylglucosamine, fumarate, glutamate, lactate, DLmalate, pyruvate, propionate and succinate. The following compounds are not utilized as carbon and energy sources: amygdalin, D-arabinose, D-cellobiose, aesculin, D-galactosamine, D-gluconolactone, lactose, D-melibiose, L-rhamnose, D-xylose, erythritol, cisaconitate, benzoate, $p$-hydroxybenzoate, hippurate, malonate, quinate, salicylate, suberate and D-tartrate. The following compounds are utilized as sole carbon, nitrogen and energy sources: L-alanine, L-asparagine, L-glutamine, L-ornithine, L-proline and L-serine. The following compounds are not utilized as sole carbon, nitrogen and energy sources: L-allantoin, L-aspartic acid, betaine, creatine, ethionine, L-isoleucine, Lmethionine, putrescine, sarcosine, L-tryptophan and L-valine.

Isolated from hypersaline habitats and from salted food. The $\mathrm{G}+\mathrm{C}$ content of the DNA is between $49 \cdot 4$ and $50.5 \mathrm{~mol} \%$. The type strain is NCIMB $701^{\mathrm{T}}$.

The description of this strain is the same as that given above for the species, except that acid is produced 
Table 1. Divergence of phenotypic characteristics between $S$. costicola and strain $\mathrm{DV}^{\top}$

Data for S. costicola were taken from Garcia et al. (1987) and Farmer \& Hickman-Brenner (1992).

\begin{tabular}{|lcc|}
\hline Characteristic & Strain DV & S. costicola \\
\hline Growth without $\mathrm{NaCl}$ & + & - \\
Growth in the presence of & - & + \\
$20 \% \mathrm{NaCl}$ & & - \\
Anaerobic gas production & + & - \\
from glucose & & - \\
Hydrolysis of starch & + & + \\
Growth at $50{ }^{\circ} \mathrm{C}$ & + & + \\
Fermentation of: & & + \\
Galactose & - & + \\
Mannose & - & \\
Mannitol & - & + \\
Sucrose & - & + \\
Aerobic growth on: & & - \\
L-Alanine & - & + \\
Lactate & - & + \\
Mannose & + & \\
Mannitol & - & \\
\hline
\end{tabular}

from D-xylose, casein is hydrolysed and D-malate and propionate are utilized as sole sources of carbon and energy. The $\mathrm{G}+\mathrm{C}$ content of the DNA of the type strain is $50 \cdot 0(\mathrm{CsCl})$ or $49 \cdot 9\left(T_{\mathrm{m}}\right) \mathrm{mol} \%$.

\section{Description of Salinivibrio costicola subsp. vallismortis subsp. nov.}

Salinivibrio costicola subsp. vallismortis (val.lis. mor'tis. L. gen. n. vallis of the valley; L. gen. n. mortis of death; M. L. fem. n. vallismortis of the valley of death, named after Death Valley, California, USA).

Cells are Gram-negative, non-sporulating, short, curved rods, $1.0-1.8 \times 0.5-0.6 \mu \mathrm{m}$, highly motile by means of one or rarely two subpolar flagella. Cells occur singly, in pairs or rarely in chains. Colonies (up to $3 \mathrm{~mm}$ ) are round with entire edges, smooth, convex, opaque and creamy white. Halotolerant. Growth occurs at $\mathrm{NaCl}$ concentration of $0-12 \cdot 5 \%$. Optimal growth occurs at $2.5 \% \mathrm{NaCl}$. Mesophilic. Optimum temperature for growth is $37^{\circ} \mathrm{C}$, growth occurs at $20-50{ }^{\circ} \mathrm{C}$. Growth occurs at $\mathrm{pH} 5 \cdot 5-8 \cdot 2$; optimum $\mathrm{pH}$ for growth is $7 \cdot 3$. No growth factors are required for growth, but yeast extract enhances growth. Either organic or inorganic nitrogen sources are sufficient. Resistant to streptomycin $\left(200 \mu \mathrm{g} \mathrm{ml}^{-1}\right)$, penicillin-G $\left(250 \mu \mathrm{g} \mathrm{ml}^{-1}\right)$, D-cycloserine and tetracycline (both $\left.600 \mu \mathrm{g} \mathrm{ml}^{-1}\right)$.

Facultative anaerobe. Chemoorganotrophic. Oxidaseand catalase-positive. Gelatin, starch and lipid (Tween 80) are hydrolysed. Arginine dihydrolase and VogesProskauer tests are positive. Aesculin and urea are not hydrolysed. Indole, lysine and ornithine decarboxylase and $\beta$-galactosidase tests are negative. Fumarate, nitrate and sulfate are not reduced. No growth occurs with $\mathrm{H}_{2} / \mathrm{CO}_{2}$.

D-Glucose, D-mannose, sucrose, trehalose, starch, adipate, caprate, D-gluconate, pyruvate, L-glutamic acid and yeast extract are metabolized aerobically. Slight growth occurs on D-xylose, L-histidine and L-proline. The following compounds are not used: L-arabinose, cellobiose, D-galactose, D-galacturonate, lactose, maltose, L-rhamnose, salicin, citrate, 2oxoglutarate, DL-lactate, L-malate, malonate, phenylacetate, propionate, valerate, ethanol, D-mannitol, $m$ inositol, D-sorbitol, DL- $\alpha$-alanine, $\beta$-alanine, L-leucine, L-serine, L-tyrosine, benzoate, $p$-hydroxybenzoate, betaine, sarcosine and spermine.

Cellobiose, fructose, D-glucose, maltose, mannose, trehalose, $\mathrm{N}$-acetylglucosamine, glycogen, starch and pyruvate are fermented. The major products from glucose fermentation are ethanol, isobutyrate, propionate, lactate, formate and $\mathrm{CO}_{2}$. The following compounds are not fermented: arabinose, galactose, lactose, melibiose, raffinose, rhamnose, ribose, sucrose, xylose, adonitol, dulcitol, erythritol, glycerol, inositol, mannitol, methanol, sorbitol, formate, acetate, butyrate, propionate, ascorbate, citrate, fumarate, lactate, oxalate, succinate, tartrate, betaine, methylamine, trimethylamine, sarcosine, Casamino acids, cellulose, chitin and pectin.

The $\mathrm{G}+\mathrm{C}$ content of DNA is $50 \mathrm{~mol} \%$ (HPLC). The type strain is strain $\mathrm{DV}^{\mathrm{T}}\left(=\mathrm{DSM} 8285^{\mathrm{T}}\right)$, which was isolated from Death Valley, California, USA.

\section{ACKNOWLEDGEMENTS}

This research was supported in part by the Australian Research Council (to B.K.C.P.). We are indebted to F. Verhé for technical assistance.

\section{REFERENCES}

Andrews, K. T. \& Patel, B. K. C. (1996). Fervidobacterium gondwanense sp. nov., a new thermophilic anaerobic bacterium isolated from nonvolcanically heated geothermal waters of the Great Artesian Basin of Australia. Int J Syst Bacteriol 46, 265-269.

Balch, W. E., Fox, G. E., Magrum, L. J., Woese, C. R. \& Wolfe, R. S. (1979). Methanogens: reevaluation of a unique biological group. Microbiol Rev 43, 260-296.

Baumann, P. \& Schubert, R. H. W. (1984). Family II. Vibrionaceae. In Bergey's Manual of Systematic Bacteriology, vol. 1, pp. 516-517. Edited by N. R. Krieg \& J. G. Holt. Baltimore: Williams \& Wilkins.

Cord-Ruwisch, R. (1985). A quick method for the determination of dissolved and precipitated sulfides in cultures of sulfatereducing bacteria. J Microbiol Methods 4, 33-36.

Cord-Ruwisch, R., Ollivier, B. \& Garcia, J.-L. (1986). Fructose degradation by Desulfovibrio sp. in pure culture and in coculture with Methanospirillum hungatei. Curr Microbiol 13, 285-289.

Farmer, J. J. \& Hickman-Brenner, F. W. (1992). The genera Vibrio and Photobacterium. In The Prokaryotes, 2nd edn, vol. 3, pp. 
2952-3001. Edited by A. Balows, H. G. Trüper, M. Dworkin, W. Harder \& K. H. Schleifer. New York: Springer.

Felsenstein, J. (1993). PHYLIP (Phylogenetic Inference Package) version 3.51c. Distributed by the author. Department of Genetics, University of Washington, Seattle, USA.

Galinski, E. A. \& Trüper, H. G. (1982). Betaine, a compatible solute in the extremely halophilic phototrophic bacterium Ectothiorhodospira halochloris. FEMS Microbiol Lett 13, $357-360$

Garcia, M. T., Ventosa, A., Ruiz-Berraquero, F. \& Kocur, M. (1987). Taxonomic study and amended description of Vibrio costicola. Int J Syst Bacteriol 37, 251-256.

Hungate, R. E. (1969). A roll tube method for the cultivation of strict anaerobes. In Methods in Microbiology, vol. 3B, pp. 117-132. Edited by J. R. Norris \& D. W. Ribbons. New York: Academic Press.

Jukes, T. H. \& Cantor, C. R. (1969). Evolution of protein molecules. In Mammalian Protein Metabolism, pp. 211-232. Edited by H. N. Munro. New York: Academic Press.

Klug, M., Boston, P., Francois, R., Gyure, R., Javor, B., Tribble, G. \& Vairavamurty, A. (1985). Sulfur reduction in sediments of marine and evaporite environments. In The Global Sulfur Cycle (NASA technical memorandum 87570), pp. 128-157. Edited by D. Sagan. Greenbelt, MD: National Aeronautics and Space Administration.

Lai, M. C. \& Gunsalus, R. P. (1992). Glycine betaine and potassium ion are the major compatible solutes in the extremely halophilic methanogen Methanohalophilus strain Z7302. J Bacteriol 174, 7474-7477.

Lai, M. C., Sowers, K. R., Robertson, D. E., Roberts, M. F. \& Gunsalus, R. P. (1991). Distribution of compatible solutes in the halophilic methanogenic archaebacteria. $J$ Bacteriol 173, 5352-5358.

Larsen, H. (1962). Halophilism. In The Bacteria, vol. 4, pp. 297-342. Edited by I. C. Gunsalus \& R. Y. Stanier. New York: Academic Press.

Liaw, H. J. \& Mah, R. A. (1992). Isolation and characterization of Haloanaerobacter chitinovorans gen. nov., sp. nov., a halophilic, anaerobic, chitinolytic bacterium from a solar saltern. Appl Environ Microbiol 58, 260-266.

Macy, J. M., Snellen, J. E. \& Hungate, R. E. (1972). Use of syringe methods for anaerobiosis. Am J Clin Nutr 25, 1318-1323.

Maidak, B. L., Olsen, G. J., Larsen, N., Overbeek, R., McCaughey, M. J. \& Woese, C. R. (1996). The Ribosomal Database Project (RDP). Nucleic Acids Res 24, 82-85.

Mechichi, T., Labat, M., Woo, T. H. S., Thomas, P., Garcia, J.-L. \& Patel, B. K. C. (1998). Eubacterium aggregans sp. nov., a new homoacetogenic bacterium from olive mill wastewater treatment digestor. Anaerobe 4, 283-291.

Mellado, E., Moore, E. R. B., Nieto, J. J. \& Ventosa, A. (1996). Analysis of 16S rRNA gene sequences of Vibrio costicola strains: description of Salinivibrio costicola gen. nov., comb. nov. Int J Syst Bacteriol 46, 817-821.
Mesbah, M., Premachandran, U. \& Whitman, W. B. (1989). Precise measurement of the $\mathrm{G}+\mathrm{C}$ content of deoxyribonucleic acid by high-performance liquid chromatography. Int $J$ Syst Bacteriol 39, 159-167.

Ollivier, B., Caumette, P., Garcia, J.-L. \& Mah, R. A. (1994). Anaerobic bacteria from hypersaline environments. Microbiol Rev 58, 27-38.

Oren, A. (1988). Anaerobic degradation of organic compounds at high salt concentrations. Antonie Leeuwenhoek 54, 267-277.

Pitcher, D. G., Saunders, N. A. \& Owen, R. J. (1989). Rapid extraction of bacterial genomic DNA with guanidium thiocyanate. Lett Appl Microbiol 8, 151-156.

Ramos-Cormenzana, A. (1993). Ecology of moderately halophilic bacteria. In The Biology of Halophilic Bacteria, pp. 55-86. Edited by R. H. Vreeland \& L. I. Hochstein. Boca Raton: CRC Press.

Redburn, A. C. \& Patel, B. K. C. (1993). Phylogenetic analysis of Desulfotomaculum thermobenzoicum using polymerase chain reaction-amplified 16S rRNA-specific DNA. FEMS Microbiol Lett 113, 81-86.

Reed, R. H., Borowitzka, L. J., Mackay, M. A., Chudek, J. A., Foster, R., Warr, S. R. C., Moore, D. J. \& Stewart, W. D. P. (1986). Organic solute accumulation in osmotically stressed cyanobacteria. FEMS Microbiol Rev 39, 51-56.

Robertson, D. E., Noll, D., Roberts, M. F., Menaia, J. A. G. F. \& Boone, D. R. (1990). Detection of the osmoregulator betaine in methanogens. Appl Environ Microbiol 56, 563-565.

Robertson, D. E., Lai, M. C., Gunsalus, R. P. \& Roberts, M. F. (1992). Composition, variation, and dynamics of major osmotic solutes in Methanohalophilus strain FDF1. Appl Environ Microbiol 58, 2438-2443.

Smibert, R. M. \& Krieg, N. R. (1981). General characterization. In Manual of Methods for General Bacteriology, pp. 409-443. Edited by P. Gerhardt, R. E. G. Murray, R. N. Sostilow, E. W. Nester, W. A. Wood, N. R. Krieg \& G. B. Philips. Washington, DC: American Society for Microbiology.

Stackebrandt, E. \& Goebel, B. M. (1994). Taxonomic note: a place for DNA-DNA reassociation and 16S rRNA sequence analysis in the present species definition in bacteriology. Int $J$ Syst Bacteriol 44, 846-849.

Tamaoka, J. \& Komagata, K. (1984). Determination of DNA base composition by reverse-phase high-performance liquid chromatography. FEMS Microbiol Lett 25, 125-128.

Vreeland, R. H. \& Hochstein, L. I. (1993). The Biology of Halophilic Bacteria. Boca Raton: CRC Press.

Winker, S. \& Woese, C. R. (1991). A definition of the domain Archaea, Bacteria and Eucarya in terms of small subunit ribosomal RNA characteristics. Syst Appl Microbiol 13, 161-165.

Zeikus, J. G. (1983). Metabolic communication between biodegradative populations in nature. Symp Soc Gen Microbiol 34, 423-462. 